\title{
32. UPPER CRETACEOUS TO PALEOCENE MAGNETOSTRATIGRAPHY OF DEEP SEA DRILLING PROJECT SITE 605, NORTHWEST ATLANTIC1
}

\author{
J. Bruins and J. E. van Hinte, Instituut voor Aardwetenschappen, Vrije Universiteit, Amsterdam \\ and \\ J. D. A. Zijderveld, Paleomagnetisch Laboratorium "Fort Hoofddijk," Rijksuniversiteit Utrecht²
}

\begin{abstract}
Natural Remanent Magnetization (NRM) was measured for regularly spaced samples from the 620-m-thick, lower middle Eocene to upper Maestrichtian section of DSDP Site 605. The total NRM of the Eocene chalks was too low $(5-50 \mu \mathrm{A} / \mathrm{m})$ to establish a reliable magnetic polarity stratigraphy. However, the results from the somewhat more clayrich Paleocene-upper Maestrichtian section are useful.

A fourfold quality classification of the results of progressive demagnetization studies aided in determining the polarity of the original remanence. Two types (1 and 2a) showed a Characteristic Remanent Magnetization (ChRM) direction with reversed and normal polarity, respectively; the third type (2b) can be interpreted as having a reversed ChRM, which could not be cleaned, whereas the fourth type (3) is considered to be unreliable.

The Site 605 magnetic polarity stratigraphy compares well with published sections, adding important detail to the correlation with planktonic microfossil zones and, hence, to the resolution of this portion of the time scale (C24-C32 on the Berggren et al., 1985, scale). The Cretaceous/Tertiary boundary occurs in a reversed polarity zone that has been correlated with Subchron C29r. We suspect the presence of an unconformity at the boundary between lithostratigraphic Units Va and IV a location which is also the level of Reflection Horizon A*.
\end{abstract}

\section{INTRODUCTION}

During DSDP Leg 93, Upper Cretaceous through lower middle Eocene sediments, including the Cretaceous/ Tertiary boundary, were cored at Site 605 in the North Atlantic, located on the upper continental rise, northeast of Norfolk at $38^{\circ} 44.53^{\prime} \mathrm{N}$ and $72^{\circ} 36.55^{\prime} \mathrm{W}$ (Fig. 1). The objective of this study is to obtain a detailed magnetic polarity stratigraphy and to correlate the paleomagnetic results with the biostratigraphy.

The Upper Cretaceous-Paleogene magnetic polarity stratigraphy has been studied in marine and terrestrial sediments from land sections and several DSDP holes. At Gubbio, Italy, an Upper Cretaceous-Paleocene magnetic polarity stratigraphy has been established on pelagic limestones by Alvarez et al. (1977). This section has been proposed as a reference section for Late Cretaceous-early Paleocene magnetostratigraphy (Lowrie et al., 1982). More recently, the magnetic polarity stratigraphy at Gubbio has been extended through the uppermost Paleocene into the upper Eocene by Napoleone et al. (1983). The results of paleomagnetic studies of Upper Cretaceous-lower Eocene pelagic carbonate rocks in the Venetian Alps (Channell and Medizza, 1981) and of pelagic limestones at other localities in Umbria (Lowrie et al., 1982) are consistent with the reference section at Gubbio. Upper Cretaceous-Paleogene sections recovered in DSDP holes have been studied paleomagnetically from

\footnotetext{
${ }^{1}$ van Hinte, J. E., Wise, S. W., Jr., et al., Init. Repts. DSDP, 93: Washington (U.S. Govt, Printing Office)

Addresses: (Bruins, present address) 32 Oriental Road, Woking, Surrey GU22 7AW, United Kingdom; (van Hinte) VU-Instituut voor Aardwetenschappen, P.O. Box 7161, 1007 MC, Amsterdam, The Netherlands; (Zijderveld) Paleomagnetisch Laboratorium "Fort Hoofddijk," Budapestlaan 17, 3584 CD, Utrecht, The Netherlands.
}

Site 384 (Larson and Opdyke, 1979, Leg 43, North Atlantic), Sites 522, 523, 524 (LaBrecque et al., 1983, Tauxe et al., 1983, Leg 73, South Atlantic), Sites 525, 527, 528, 529 (Chave, 1984, Leg 74, South Atlantic) and Site 530 (Keating and Herrero-Bervera, 1984, Leg 75, South Atlantic).

All published paleomagnetic studies of marine sediments find the Cretaceous/Tertiary boundary, as determined by paleontology, in reversed magnetozone C29r. However, magnetic polarity stratigraphy has also been determined for nonmarine Upper Cretaceous-Paleocene sediments in the San Juan Basin of New Mexico. In these terrestrial sediments the supposed $\mathrm{K} / \mathrm{T}$ boundary, drawn at the last occurrence of Tyrannosaurus rex, has been reported (Butler et al., 1977) to be higher, at the base of C29 normal. This discrepancy may no longer exist, since Smit and van der Kaars (1984) found that in a similar setting (Hell Creek area, Montana) the uppermost dinosaurs occur with Paleocene fossils on point bar deposits and are reworked. All studies are now essentially in accordance, and the resulting polarity stratigraphy is directly compatible with the seafloor anomaly pattern as summarized by Ness et al., (1980) and Lowrie and Alvarez (1981) and correlated to the planktonic microfossil zonations by Hardenbol and Berggren (1978) and Berggren et al. (1985).

Because of the moderate sedimentation rate, the almost complete recovery, and the determination of most of the foraminiferal and nannofossil zones, the Upper Cretaceous-Paleogene sediments of Site 605 offer an excellent opportunity to correlate the magnetostratigraphy with the marine biostratigraphy, to provide numerical ages to the planktonic zonal boundaries and to verify the general assumption of a constant seafloor spreading 


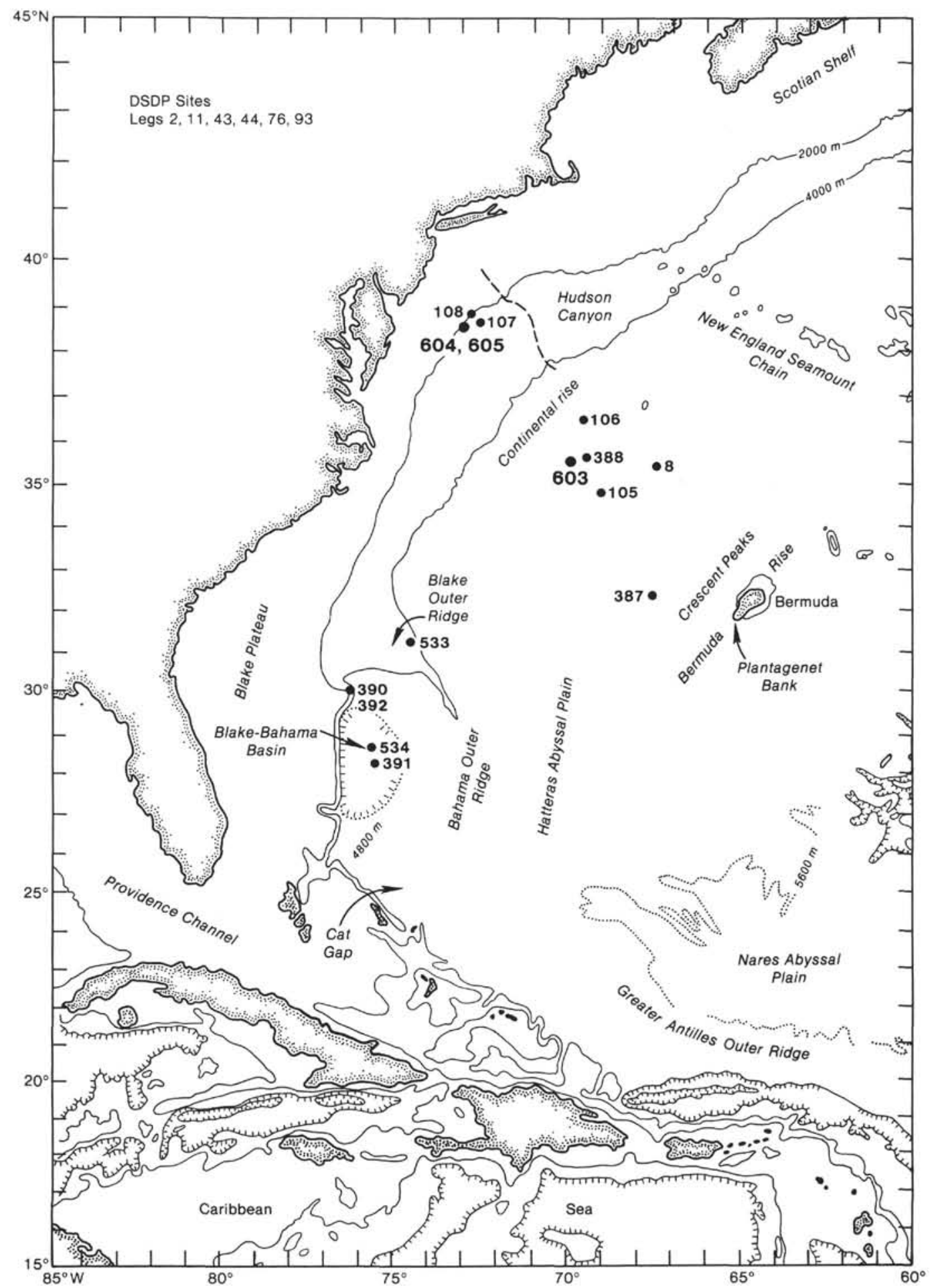

Figure 1. Main physiographic features of the North American Basin and location of the DSDP sites.

rate. A comparison with recent work on marine sediments and especially with the recently published results of Leg 73 (Hsü et al., 1984) will improve and complement the Upper Cretaceous-Paleogene timescale.

\section{LITHOLOGY}

At Site 605 about $620 \mathrm{~m}$ of Upper Cretaceous-lower middle Eocene sediments were penetrated and cored, with
$80 \%$ recovery. The shipboard scientists divided the sediments into five major units, one with two subunits (Fig. 2). They are, from the bottom up:

Unit V: Subunit VB, $56.5 \mathrm{~m}$ of Maestrichtian, burrowed, olive gray, clay-rich foraminifer-nannofossil limestone.

Subunit VA, $19.8 \mathrm{~m}$ of lower Paleocene, burrowed, dark greenish gray, glauconite-bearing and silt-rich, clay- 


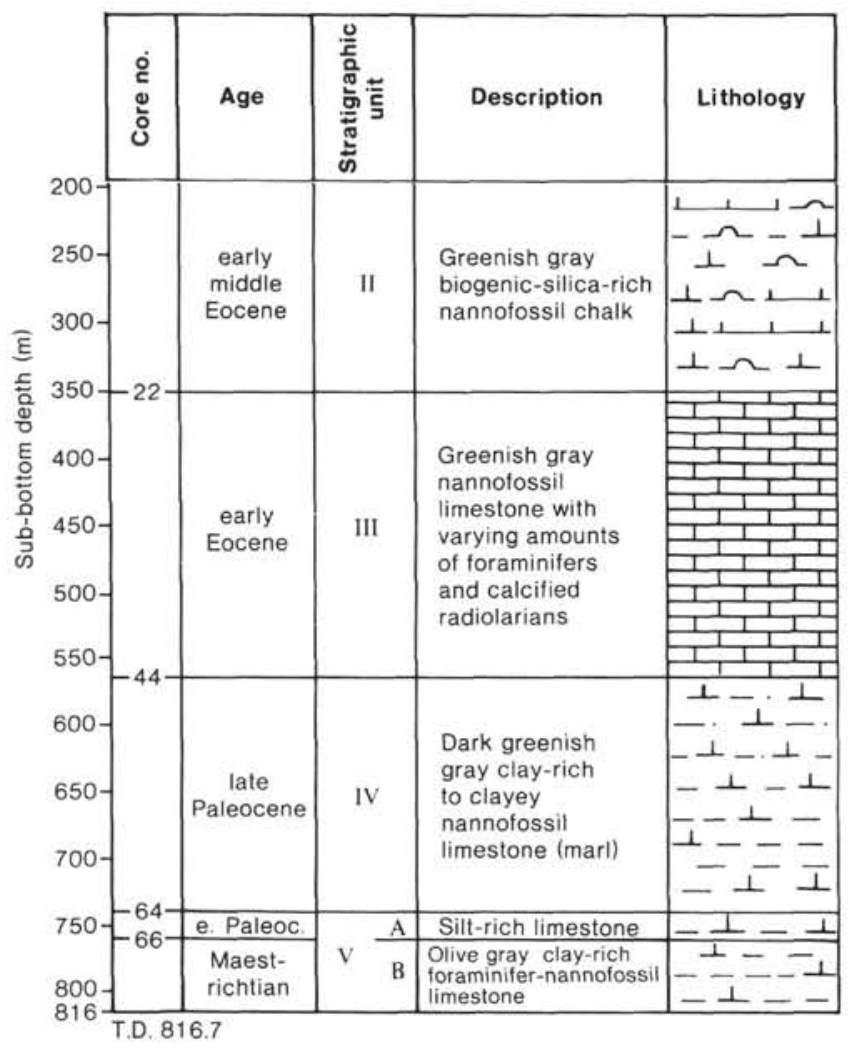

Figure 2. Maestrichtian-Eocene stratigraphic column for Site 605.

ey nannofossil limestone. The boundary between Unit IV and Subunit Va is truncational.

Unit IV: $176 \mathrm{~m}$ of upper Paleocene, burrowed, dark greenish gray, clay-rich to clayey nannofossil limestone.

Unit III: $214 \mathrm{~m}$ of lower Eocene, burrowed, greenish gray nannofossil limestone, with varying amounts of foraminifers and calcified radiolarians.

Unit II: $152 \mathrm{~m}$ of lower middle Eocene, greenish gray, biosiliceous nannofossil chalk rich in radiolarians and diatoms.

More details are presented in the Site 605 chapter (this volume).

\section{PROCEDURES}

Aboard ship, 643 cylindrical samples ( $2.54 \mathrm{~cm}$ in diameter), oriented perpendicularly to the core axis, were taken between 202.3 and $816.7 \mathrm{~m}$ sub-bottom depth (cores 7 to 71 ). If recovery allowed, two samples were taken from each $1.5 \mathrm{~m}$ core section, at approximately $80 \mathrm{~cm}$ distance. Samples were packed in tissue and placed in a plastic sample vial, which was capped and sealed. In the laboratory, the samples were cut to a length/diameter ratio of 0.85 to fit our magnetometer.

All measurements are made on a two-axis ScT-cryogenic magnetometer. In general, the total Natural Remanent Magnetization (NRM) intensities are very low. The samples of Units II and III (Eocene) show intensities in the range of $5-200 \mu \mathrm{A} / \mathrm{m}$, the bulk of the samples varying between $5-50 \mu \mathrm{A} / \mathrm{m}$, below or close to the magnetic intensity of the sample-holder (10-15 $\mu \mathrm{A} / \mathrm{m})$ of the cryogenic magnetometer. Figure 3 illustrates the total NRM intensities of Units II and III and the NRM inclinations. Note the very large dispersion of directions. The total NRM intensities of Units IV and V are somewhat higher and vary from 30 to $400 \mu \mathrm{A} / \mathrm{m}$, but a large dispersion of directions is also apparent there (Fig. 4).

Several samples of different lithology were saturated in a direct field of $2 \mathrm{~T}$ maximum to determine the remanent coercive force $(\mathrm{Hcr})$ and to identify the nature of magnetization. More than $95 \%$ of the intensity of the saturation remanence is reached after 0.3-0.4 T (Fig. 5). The Her varies in the range of $0.04-0.07 \mathrm{~T}$. These values indicate that very fine grained magnetite is the magnetic mineral (Dankers, 1978; Hartstra, 1982). The mean intensity of the saturation remanence of Units II and III is a factor 2 below that of Units IV and V, indicating a smaller amount or a different grain size of the magnetic minerals. The first possibility is supported by the fact that the percentage of clay in Units II and III is lower than in Units IV and V.

Pilot samples were progressively demagnetized up to total demagnetization, either in alternating fields (up to $0.1 \mathrm{~T}$ ), or by stepwise heating (up to $400^{\circ} \mathrm{C}$ ), or by a combination of stepwise heating (up to $190^{\circ} \mathrm{C}$ ) and alternating fields. All 27 pilot samples of Units II and III revealed unreliable results (signal/noise ratio $\leq 1$ ) and the remaining samples of these units were therefore not further analyzed. Somewhat better, although not unequivocal, results were obtained from the pilot samples of Units IV and V by using alternating fields increased in small steps up to a maximum of $200 \mathrm{mT}$. At every step each orthogonal axis of the sample was separately demagnetized and measured (Zijderveld, 1967; Langereis, 1979). The combination of the three components (A-, B-, and C-axis) gives the total vector. Up to total demagnetization, this procedure then was applied to all remaining samples of Units IV and V.

\section{INTERPRETATION}

The direction of the vertical projection of the Characteristic Remanent Magnetization (ChRM) vector determines the sign of the inclination and hence the original polarity, because our samples have only a vertical and no horizontal orientation. Still, the change in the relative declination during demagnetization can point to normal or reversed polarity. Zijderveld plots (Zijderveld, 1967) of all samples can be sorted into four types. Types $1(8.8 \%$ of total amount [193] of samples) and $2(82.9 \%)$ include samples where the Zijderveld plots show a ChRM vector of reversed or normal polarity, respectively (Fig. $6 \mathrm{~A}, \mathrm{~B}, \mathrm{C})$. Type 2 has been subdivided into Subtypes $2 \mathrm{a}$ $(32.6 \%)$ and $2 \mathrm{~b}(50.3 \%)$. Subtype $2 \mathrm{a}$ shows a ChRM vector decaying straight to the origin in both the vertical and horizontal projection (Fig. 6B), whereas Zijderveld plots that show decay of the remanence vector in which both the vertical and horizontal projections bypass the origin are classified as Subtype $2 \mathrm{~b}$ (Fig. $6 \mathrm{C}$ ). When the alternating field demagnetization of the samples resulted in unreliable measurements and directions they were classified as Type $3(8.3 \%)$ (Fig. 6D).

To derive the ChRM directions and consequently a magnetic polarity stratigraphy, an interpretation of Types 1 and 2 behavior was needed. In most samples of Types 1 and 2 , viscous components were removed in a peak field of 2.5-5 mT. The remaining ChRM direction of Type 1 samples shows a reversed polarity. Some of them yielded a secondary component of normal polarity, more or less antiparallel to the ChRM direction. The Subtype 2a samples clearly have a normal polarity, which could be determined in peak fields of 5-10 mT up to $100 \mathrm{mT}$.

Subtype $2 \mathrm{~b}$ behavior (bypassing the origin) is interpreted as caused by a simultaneous decay of the ChRM component and an opposite secondary component that is obviously due to the overlapping coercive spectra. After almost completely degrading the secondary component, the ChRM intensity enters the range of the noiselevel of the cryogenic magnetometer and is consequently not measurable. However, we have reasons to interpret the ChRM direction as reversed and antiparallel to the 


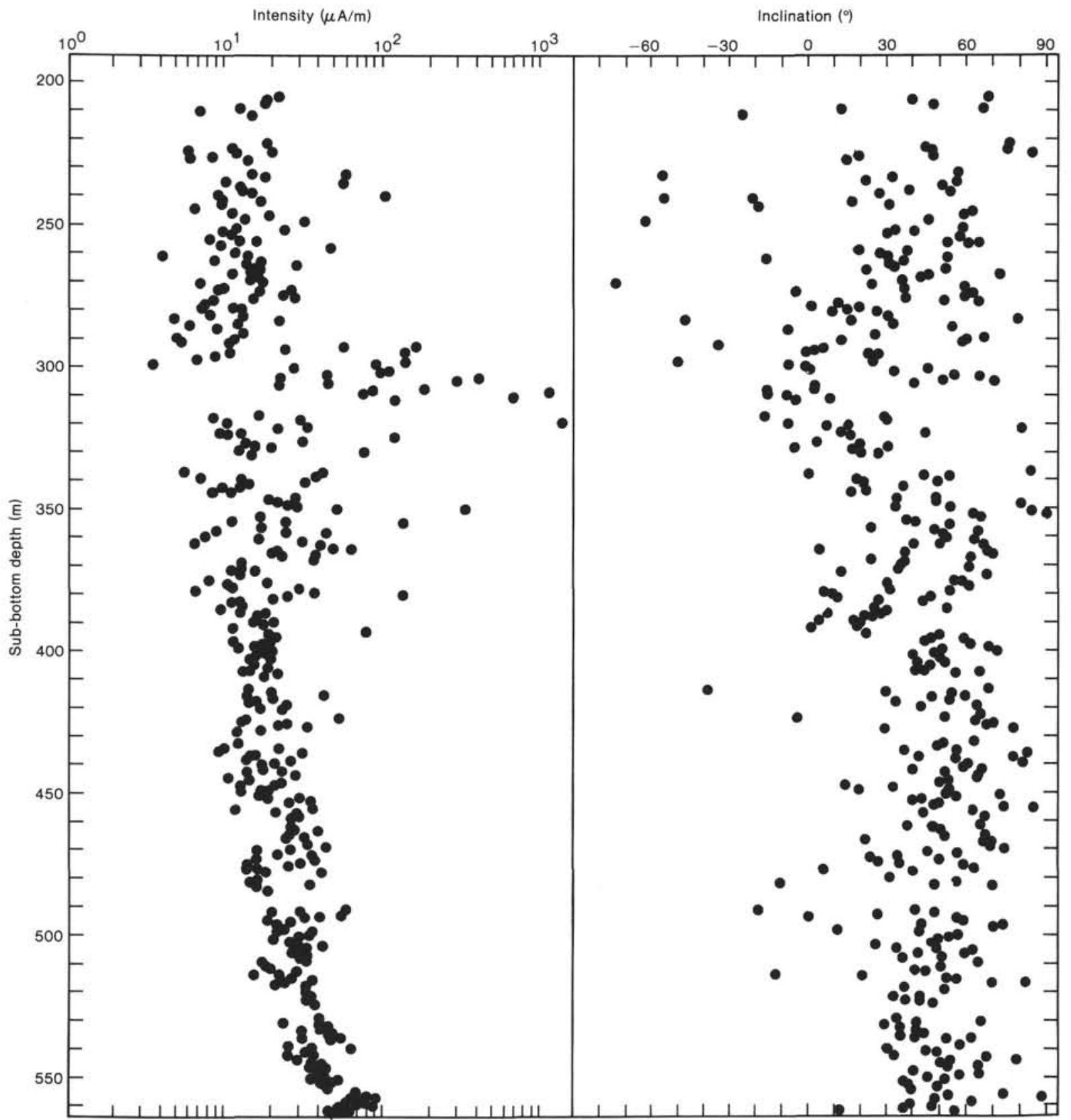

Figure 3. Total NRM intensities and inclinations of 380 samples from lithostratigraphic Units II and III (Eocene), Site 605 . Note the relatively high intensities between 290 and $310 \mathrm{~m}$.

secondary component of normal polarity. First, Subtype $2 \mathrm{~b}$ is not randomly distributed throughout the section, but is restricted to certain intervals together with Type 1, not with Subtype 2a. Secondly, Type 1 confirms the interpretation of Subtype $2 b$, showing the same antiparallelism and bypassing of the origin. Thirdly, in several samples of Subtype $2 b$, the inclination becomes negative or very small (a few degrees) in the last demagnetization step(s). Fourthly, the relative declination shows in most cases an angular change of $90^{\circ}-180^{\circ}$ during the alternating field treatment whereas the declination of Subtype 2a samples remain stable. Finally, the threefold alternating field treatment of the samples excludes the possibility that the Subtype $2 \mathrm{~b}$ behavior is the result of a disturbing remanence, introduced during alternating field treatment (Langereis, 1979).

To illustrate the polarities through the section, the ChRM inclinations of Type 1 and Subtype 2a samples have been plotted versus sub-bottom depth (Fig. 7). The samples of Subtype $2 \mathrm{~b}$ and Type 3 have been indicated on the $\mathrm{I}=0$ axis, because the ChRM inclinations are not revealed. The derived magnetic polarity stratigraphy of Site 605 is illustrated in Figure 7.

\section{CORRELATION WITH THE MAGNETIC POLARITY TIME SCALE}

The magnetic polarity sequence revealed by the sediments of Site 605 can be divided into a reversed-polarity 


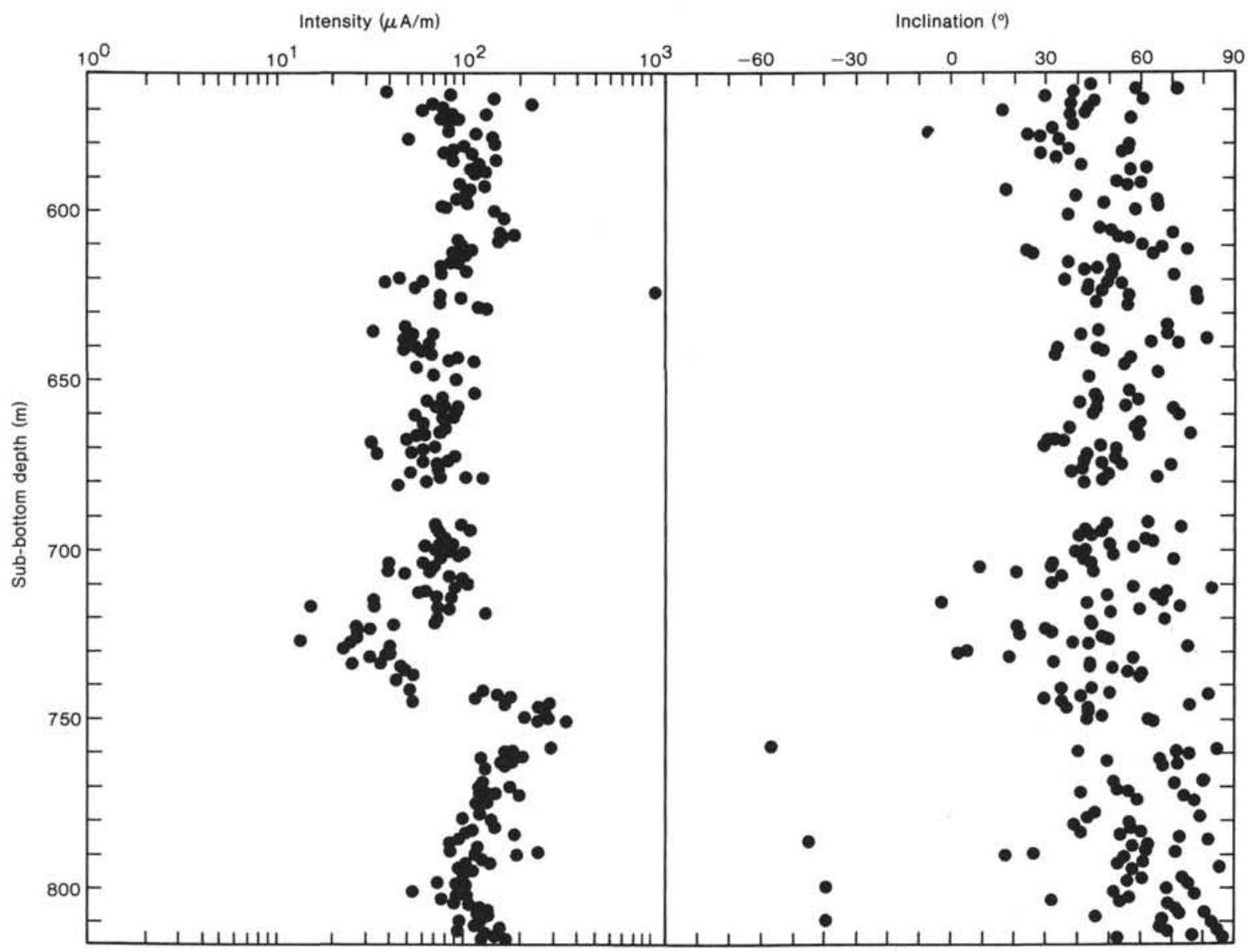

Figure 4. Total NRM intensities and inclinations of 263 samples from lithostratigraphic Units IV and V (upper Maestrichtian-Paleocene), Site 605 .

superzone with two relatively short normal-polarity zones and a mixed-polarity superzone (Fig. 7). These polarity superzones correspond, respectively, with Unit IV and Unit V. According to the biostratigraphic analysis of Units IV and V (Site 605 chapter, this volume), the magnetic polarity sequence correlates with the Late CretaceousPaleocene part of the magnetic polarity time scale (MPTS) of Berggren et al. (1985). The two polarity superzones recognized in the magnetic polarity sequence of Site 605 are also clearly apparent in the MPTS. The reversed-polarity superzone correlates with the late Paleocene part of the MPTS. Hence, the two normal-polarity zones have been identified as C25n and C26n. The mixed-polarity superzone has been compared to the Late Cretaceousearly Paleocene part of the MPTS. Biostratigraphical data place the Cretaceous/Tertiary boundary at $\mathbf{7 5 9 . 8 2}$ $\mathrm{m}$ sub-bottom depth, in a reversed-polarity zone which therefore correlates with $\mathrm{C} 29 \mathrm{r}$ (see Introduction). Consequently $\mathrm{C} 30$ and $\mathrm{C} 31$ can be identified, and the base of Site 605 is located in C32.1n (Alternative 1: solid line in Fig. 7).

However, alternative interpretations are possible for parts of the section. Poor recovery and the truncational seismostratigraphic boundary between Subunit VA and Unit IV make the identification of the magnetozones of Subunit VA rather uncertain. If the truncation is not too deep, which, according to the biostratigraphy, seems to be the case, then the identification of $\mathrm{C} 27$ and upper C28n is acceptable (Alternative 1: solid line in Fig. 7), and the unrecovered interval represents the rest of $\mathrm{C} 28 \mathrm{n}$ and C29n. But the normal polarity of the sediments in Core 65 could also be correlated with C29n (Alternative 2; dashed line in Fig. 7), in which case it is likely that $\mathrm{C} 27$, part of $\mathrm{C} 28 \mathrm{n}$, and possibly part of $\mathrm{C} 26 \mathrm{r}$ are missing. Consequently, the VA/IV boundary would mark an unconformity which would fit the $\mathrm{Kc} / \mathrm{Ta}$ seismic megasequence boundary of Vail and Mitchum (1979). We expect that shore-based paleontologic analysis will allow for an evaluation of the two interpretations.

The first interpretation of the Cretaceous magnetic polarity sequence (Alternative 1) implies very low sediment accumulation rates during Chron $\mathrm{C} 30 \mathrm{n}$ or a hiatus. However, if we disregard three weak measurements (Subtype 2b) in Cores 67 and 68 we may consider this interval to have normal polarity and to be part of $\mathrm{C} 30 \mathrm{n}$ (Alternative 2: dashed line in Fig. 7). The normal-polarity interval at the bottom of the hole then would equate with C31n and not with C32.1n. Again, the results of further shore-based paleontologic analysis may suggest which alternative is correct.

Because of samples revealing very low total NRM intensities (these samples were not further analyzed) or unreliable demagnetization results, the magnetozone boundaries could not always be precisely located between 
A. Sample 605-32-1, 119-121 cm

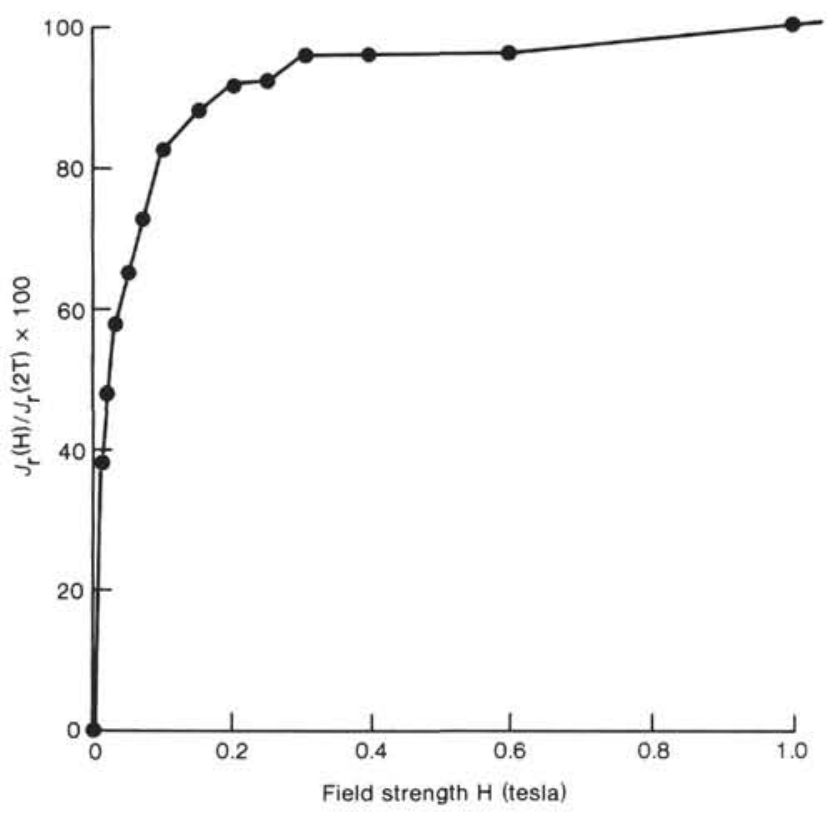

C. Sample 605-64-2, 39-41 cm

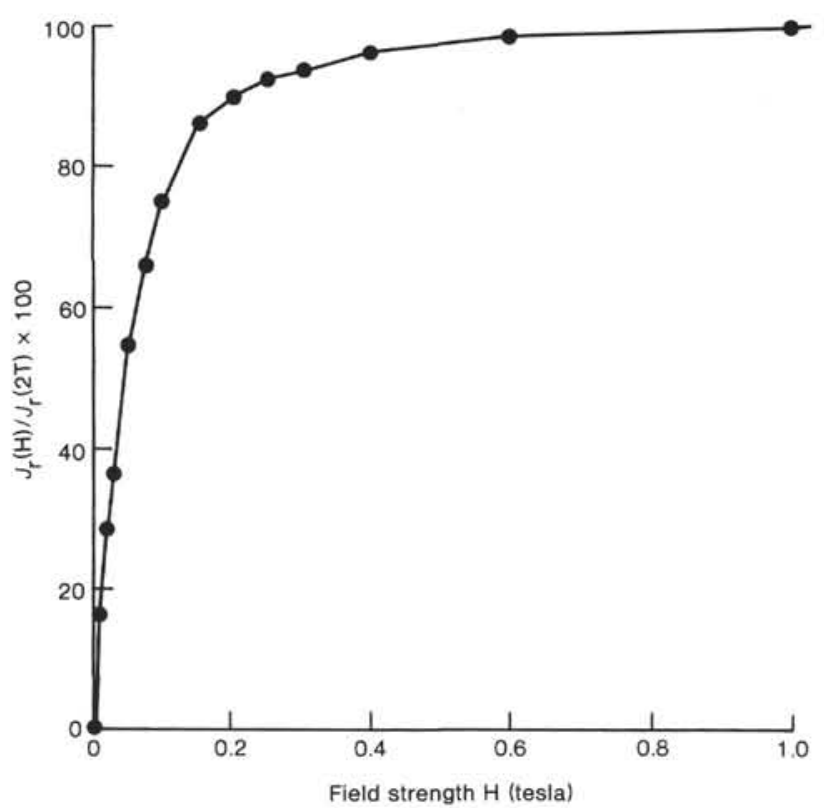

B. Sample $605-54-1,32-34 \mathrm{~cm}$

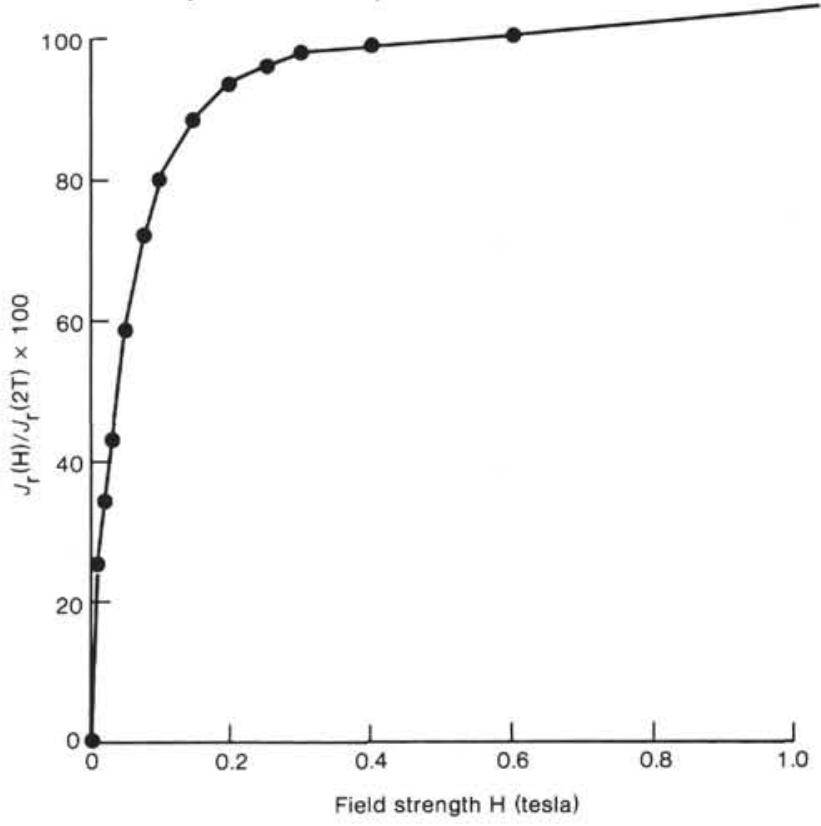

D. Sample $605-69-2,41-43 \mathrm{~cm}$

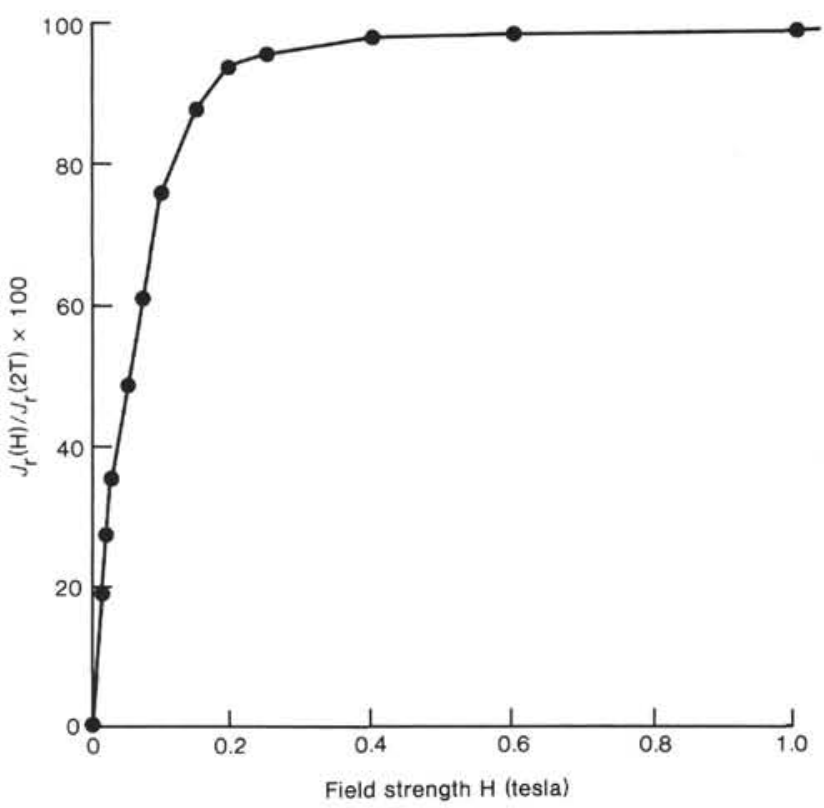

Figure 5. Magnetic saturation curves of four samples, representing different rock types, of Site 605. A. Units II and III. B. Unit IV. C. Unit VA. D. Unit $\mathrm{VB} . J_{\mathrm{r}}(\mathrm{H}) / J_{\mathrm{r}}(2 \mathrm{~T})$ represents the ratio of the magnetic remanence and the saturation remanence induced by a magnetic field of $\mathrm{H}<2 \mathrm{~T}$ and $2 \mathrm{~T}$, respectively.

two successive samples. In Table 1 we list sample numbers and sub-bottom depths between which the magnetozone boundaries are located.

\section{SEDIMENT ACCUMULATION RATES}

Calculations of the sediment accumulation rates of the Upper Cretaceous-Paleocene of Site 605 (see Table 1) are based on the numerical ages of the polarity-zone boundaries as given by Berggren et al. (1985).

In the Maestrichtian, there is an increase in average accumulation rate (Alternative 1) from 0.6 to 1.9 and $5.5 \mathrm{~cm} / 10^{3}$ year. This is followed by a drop to $0.3 \mathrm{~cm} /$ $10^{3}$ year. Yet these dramatic changes are not reflected in any facies change and therefore seem unrealistic. Either 

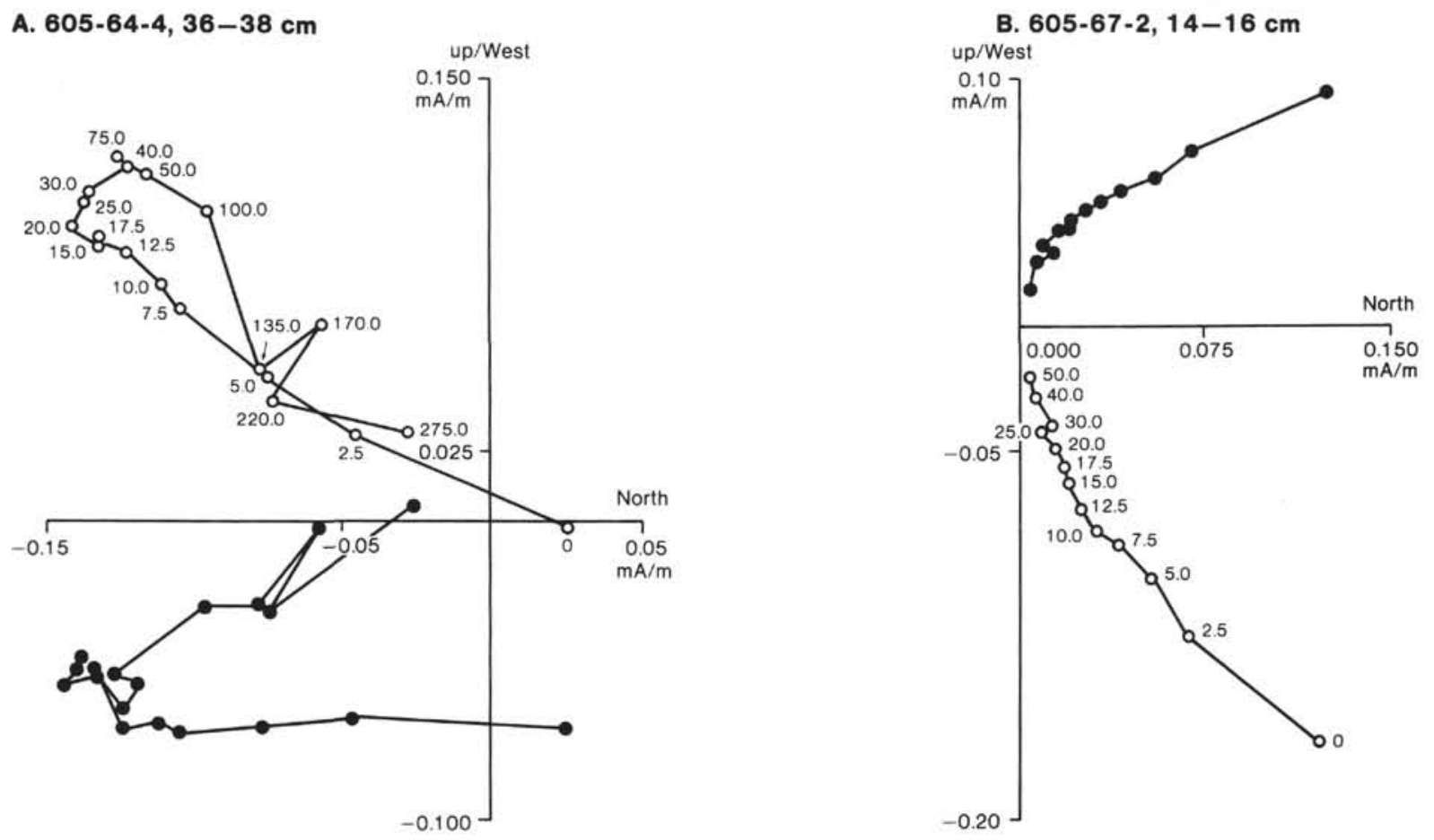

C. $605-46-2,127-129 \mathrm{~cm}$

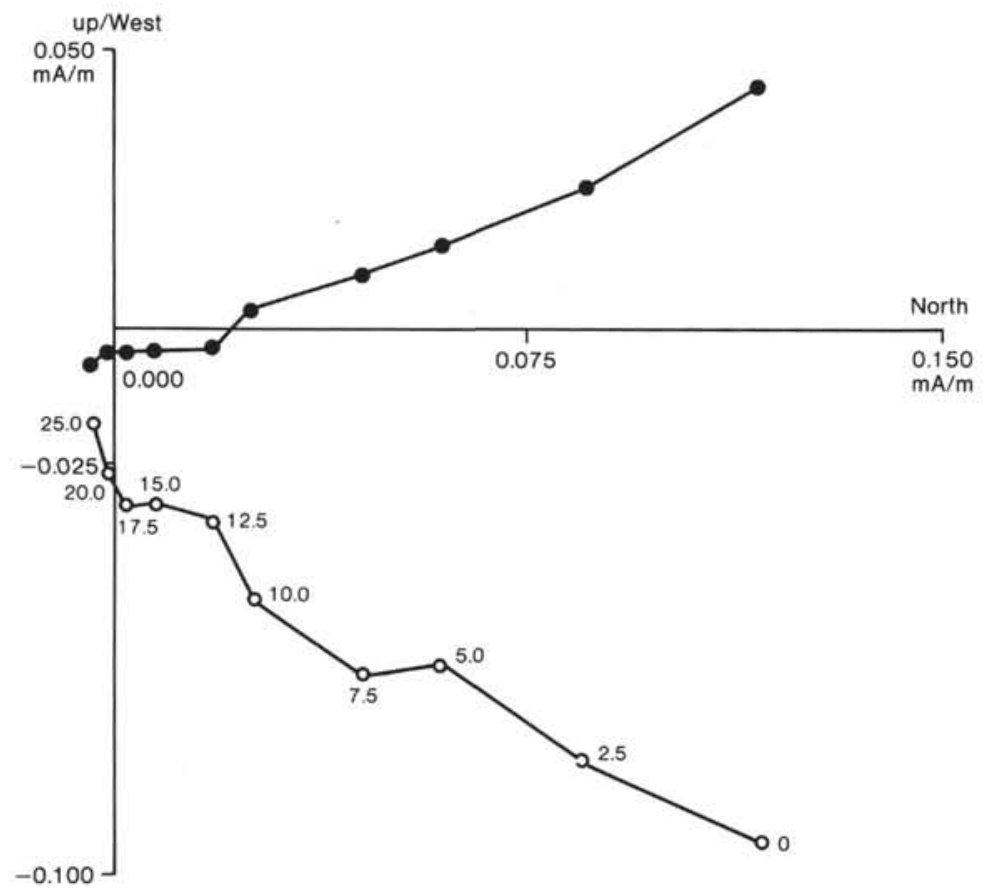

D. $605-14-5,25-27 \mathrm{~cm}$

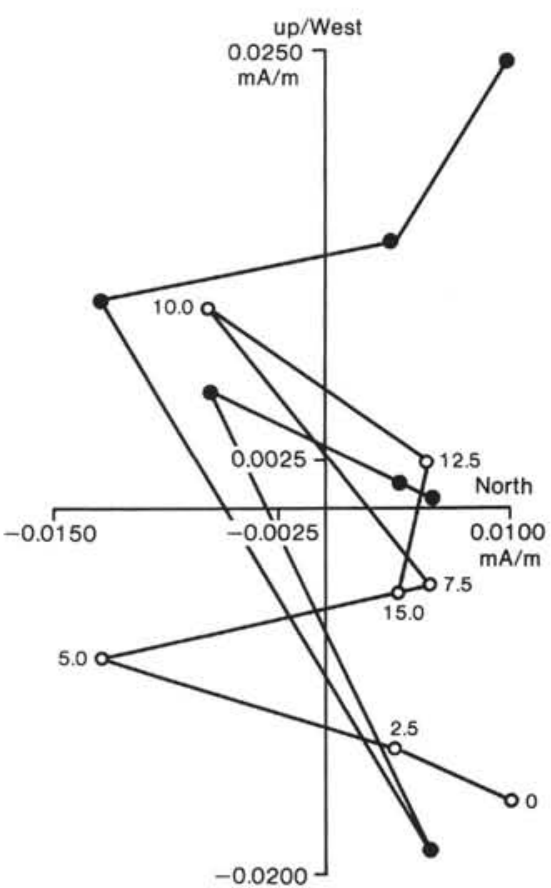

Figure 6. Representative Zijderveld diagrams, illustrating fourfold classification of demagnetization behavior. A. Type 1. B. Subtype 2a. C. Subtype 2b. D. Type 3 . Circles denote projection of end points of remanent magnetization vectors on the horizontal (solid circles) and vertical (open circles) planes. Numbers along curves refer to peak field in mT. 


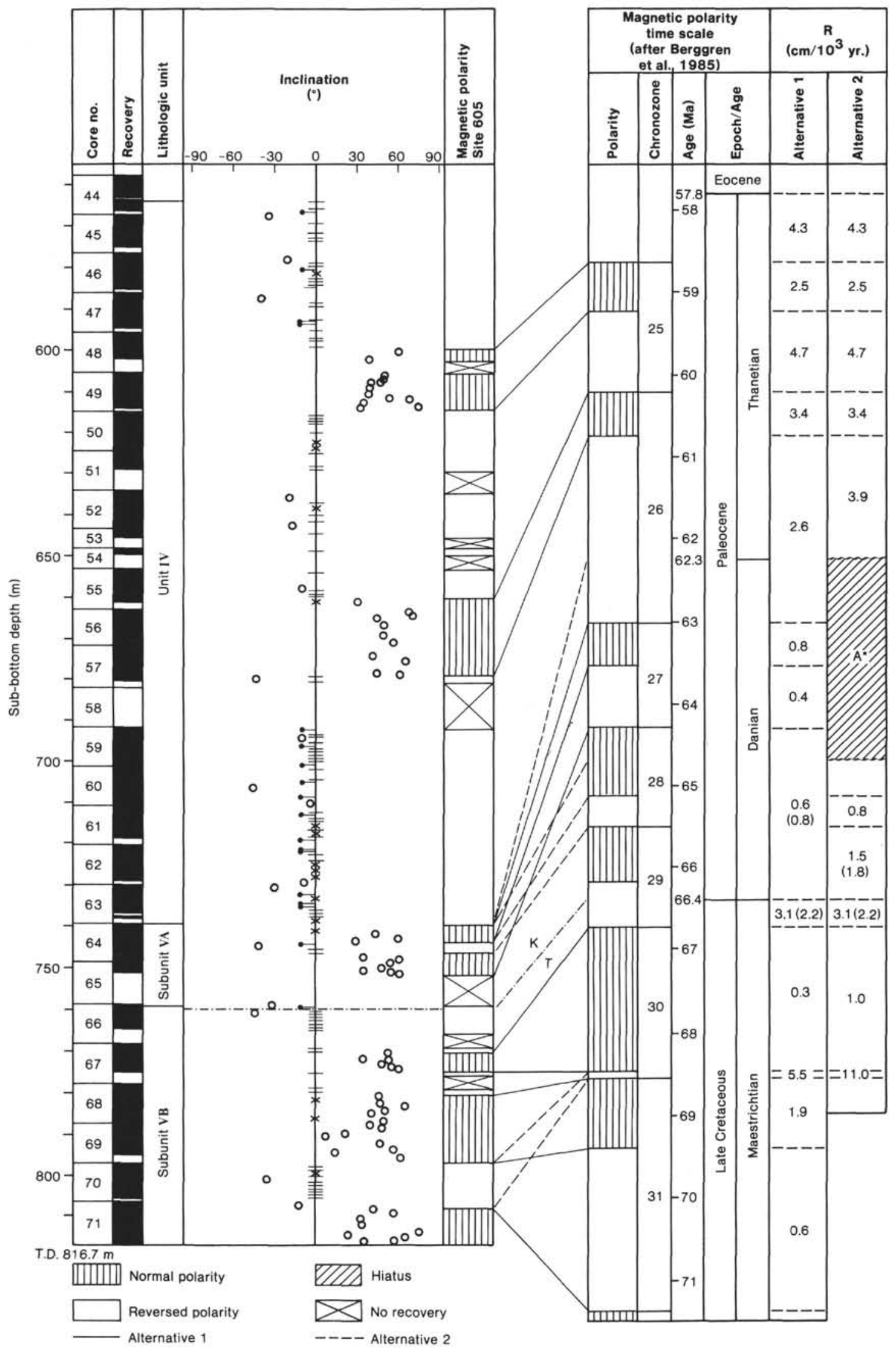

Figure 7. Correlation of the magnetic polarity stratigraphy of Site 605 with the magnetic polarity time scale of Berggren et al. (1985). $A^{*}=$ reflection Horizon $A^{*}$. Open circles: Type 1 and Subtype $2 a$ samples. Bars: Subtype $2 b$ samples. Bars with solid circles: Subtype $2 \mathrm{~b}$ samples with only a few degrees of inclination remaining after demagnetization. Crosses: Type 3 samples. $R=$ average rate of sediment accumulation in $\mathrm{cm} / 10^{3}$ year $\mathrm{K} / \mathrm{T}=$ Cretaceous $/$ Tertiary boundary. 
Table 1. Location of the magnetozone boundaries in Hole 605. Ages after Berggren et al. (1985). R represents average rate of sediment accumulation in $\mathrm{cm} / 10^{3} \mathrm{yr}$.

\begin{tabular}{|c|c|c|c|c|c|c|c|}
\hline \multirow[b]{2}{*}{$\begin{array}{l}\text { Magnetozone } \\
\text { boundary }\end{array}$} & \multirow[b]{2}{*}{$\begin{array}{l}\mathrm{Age} \\
(\mathrm{Ma})\end{array}$} & \multicolumn{3}{|c|}{ Alternative 1} & \multicolumn{3}{|c|}{ Alternative 2} \\
\hline & & $\begin{array}{l}\text { Core-Section } \\
\text { (interval in } \mathrm{cm} \text { ) }\end{array}$ & $\begin{array}{l}\text { Sub-bottom } \\
\text { depth (m) }\end{array}$ & $\mathbf{R}$ & $\begin{array}{l}\text { Core-Section }{ }^{\mathrm{a}} \\
\text { (interval in } \mathrm{cm} \text { ) }\end{array}$ & $\begin{array}{l}\text { Sub-bottom } \\
\text { depth (m) }\end{array}$ & $\mathbf{R}$ \\
\hline $\begin{array}{l}\text { Paleo./Eoc. } \\
\text { boundary }\end{array}$ & 57.80 & $44-5,33$ & 563.80 & & & & \\
\hline $\mathrm{C} 24 \mathrm{r} / \mathrm{C} 25 \mathrm{n}$ & 58.64 & $48-3,7-9$ through $48-3,134-136$ & $598.98 / 600.25$ & 4.3 & & & 4.3 \\
\hline $\mathrm{C} 25 \mathrm{n} / \mathrm{C} 25 \mathrm{r}$ & 59.24 & $49-6,98-100$ through $50-1,44-48$ & $613.99 / 615.55$ & 2.5 & & & 2.5 \\
\hline $\mathrm{C} 25 \mathrm{r} / \mathrm{C} 26 \mathrm{n}$ & 60.21 & $55-5,36-38$ through $55-6,26-28$ & $659.87 / 661.27$ & 4.7 & & & 4.7 \\
\hline $\mathrm{C} 26 \mathrm{n} / \mathrm{C} 26 \mathrm{r}$ & 60.75 & $57-5,42-44$ through $57-5,124-126$ & $678.35 / 679.35$ & 3.4 & & & 3.4 \\
\hline $\mathrm{C} 26 \mathrm{r} / \mathrm{C} 27 \mathrm{n}$ & 63.03 & $63-5,121-123$ through $64-2,39-41$ & $737.52 / 741.80$ & 2.6 & Not present & & 3.9 \\
\hline $\mathrm{C} 27 \mathrm{n} / \mathrm{C} 27 \mathrm{r}$ & 63.54 & $64-3,36-38$ through $64-3,118-120$ & $743.27 / 744.09$ & 0.8 & Not present & & \\
\hline $\mathrm{C} 27 \mathrm{r} / \mathrm{C} 28 \mathrm{n}$ & 64.29 & $64-5,47-49$ through $64-5,119-121$ & $746.38 / 747.10$ & 0.4 & Not present & & \\
\hline $\mathrm{C} 28 \mathrm{n} / \mathrm{C} 28 \mathrm{r}$ & 65.12 & Not present & & & $63-5,121-123$ through $64-2,39-41$ & $737.52 / 741.80$ & \\
\hline $\mathrm{C} 28 \mathrm{r} / \mathrm{C} 29 \mathrm{n}$ & 65.50 & Not present & & 0.6 & $64-3,36-38$ through $64-3,118-120$ & $743.27 / 744.09$ & 0.8 \\
\hline $\mathrm{C} 29 \mathrm{n} / \mathrm{C} 29 \mathrm{r}$ & 66.17 & Not present & & $(0.8)$ & $64-5,47-49$ through $64-5,119-121$ & $746.38 / 747.10$ & \\
\hline Cret./Tert. & 66.40 & $65-1,72$ & $759.82(762.79)$ & 3.1 & & & $\begin{array}{c}(1.8) \\
3.1\end{array}$ \\
\hline C29r/C30n & 66.74 & $67-1,137-139$ through $67-2,14-16$ & $770.08 / 770.35$ & (2.2) & & & (2.2) \\
\hline $\mathrm{C} 30 \mathrm{n} / \mathrm{C} 30 \mathrm{r}$ & 68.42 & $67-4,120-122$ through $67-5,27-29$ & $774.41 / 774.98$ & 0.3 & $\begin{array}{l}6-6,28-30 \text { through } 70-1,40-42 \\
70-1,40-42 \text { through } 71-2,40-42\end{array}$ & $807.051 / 80901$ & 1.0 \\
\hline $\mathrm{C} 30 \mathrm{r} / \mathrm{C} 31 \mathrm{n}$ & 68.52 & $68-1,137-139$ through $68-2,18-20$ & $779.68 / 779.99$ & 5.5 & $70-1,40-42$ through $71-2,40-42$ & $807.51 / 809.01$ & 11.0 \\
\hline $\mathrm{C} 31 \mathrm{n} / \mathrm{C} 31 \mathrm{r}$ & 69.40 & $69-6,28-30$ through $70-1,40-42$ & $795.69 / 797.91$ & 1.9 & Not present & & \\
\hline $\mathrm{C} 31 \mathrm{r} / \mathrm{C} 32.1 \mathrm{n}$ & 71.37 & $71-1,40-42$ through $71-2,40-42$ & $807.51 / 809.01$ & 0.8 & Not present & & \\
\hline
\end{tabular}

${ }^{a}$ Unless otherwise indicated core and section no. and sub-bottom depths are the same as for Alternative 1.

our correlation with the MPTS is wrong, the section has hiatuses, or possibly the MPTS has too short an interval for $\mathrm{C} 30 \mathrm{r}$.

The other interpretation (Alternative 2) of the Cretaceous reversal pattern implies normal pelagic sediment accumulation rates $\left(1.0\right.$ and $3.1 \mathrm{~cm} / 10^{3}$ year) for most of it, except for an unrealistically high rate $\left(11 \mathrm{~cm} / 10^{3}\right.$ year) for the C30r record. The Cretaceous/Tertiary boundary has been located at $605-66-1,72 \mathrm{~cm}$, which is 759.82 $\mathrm{m}$ sub-bottom and implies a rate of accumulation for the lowermost Paleocene of $0.6 \mathrm{~cm} / 10^{3}$ year, assuming that the lowermost Tertiary normal interval is $\mathrm{C} 28 \mathrm{n}$, or $1.5 \mathrm{~cm} / 10^{3}$ year, assuming it is $\mathrm{C} 29 \mathrm{n}$. The rate of accumulation of the uppermost Cretaceous would be 3.1 $\mathrm{cm} / 10^{3}$ year. Somewhat different, and in our opinion more realistic, rates will be obtained if we take into consideration that only $6.03 \mathrm{~m}$ of the $9.0 \mathrm{~m}$ cored were recovered. Following the DSDP convention, the recovered section has been placed at the top of the cored interval. However, the core is fragmented at the Cretaceous/Tertiary boundary and it seems more likely that the debris at that boundary represents the unrecovered portion (see Site 605 chapter, this volume). This would bring the Cretaceous/Tertiary boundary $2.97 \mathrm{~m}$ lower to $762.79 \mathrm{~m}$ sub-bottom, and the sedimentation rates would be 0.8 , 1.8 , and $2.2 \mathrm{~cm} / 10^{3}$ year, respectively.

Both interpretations (Alternatives 1 and 2) of the lower Paleocene reversal pattern imply a significant and consistent increase in sediment accumulation rates at the early/late Paleocene boundary (see Fig. 7). In our secondary interpretation (Alternative 2), the increase follows a truncating event that left a considerable hiatus. We placed the event at the Danian/Thanetian boundary equating it with the sea level drop at the Kc-Ta supercycle boundary of Vail and Mitchum (1979).

The interpretation of the magnetic polarity sequence for the upper Paleocene implies a fairly constant and high rate of sediment accumulation, a constancy one would expect from the unchanged facies. The $2.5 \mathrm{~cm} /$ $10^{3}$ year for $\mathrm{C} 25 \mathrm{n}\left(2.0 \mathrm{~cm} / 10^{3}\right.$ year if the recovered section of Core 48 is placed at the bottom of the cored interval) falls somewhat out of line (the interval from the top of C26n to the Paleocene/Eocene boundary as a whole has an average rate of $4.0 \mathrm{~cm} / 10^{3}$ year and we suspect that the duration of Subchron C25n may be closer to $0.3 \mathrm{Ma}$ than to the $0.6 \mathrm{Ma}$ presently assigned to it in the MPTS.

\section{CONCLUSIONS}

The objective of this study, to obtain a detailed magnetic polarity stratigraphy of the upper Maestrichtianlower middle Eocene sediments of Site 605, has been partly achieved.

After an extensive pilot study, the Eocene sediments proved to be unsuited to paleomagnetic analysis. The remaining Paleocene and upper Maestrichtian sediments have been more useful, although the derived demagnetization data were not unequivocal. A fourfold classification of the demagnetization behavior of the samples allowed us to construct a magnetic polarity stratigraphy that can be correlated with the magnetic polarity time scale of Berggren et al. (1985). Important conclusions are: The Cretaceous/Tertiary boundary occurs in a reversed-polarity zone which we correlate with Subchron $\mathrm{C} 29$ r; consequently, the base of Site 605 is located within C31n or C32.1n and most of Chrons 24-32 can be identified. A part of the lower Paleocene is missing, because of either poor recovery or an erosional event which we would correlate with the $\mathrm{Kc} / \mathrm{Ta}$ supercycle boundary of Vail and Mitchum (1979), which we place at the boundary between lithostratigraphic Units Va and IV. This level also marks a seismic sequence boundary often mapped as Reflection Horizon A*.

Because the construction of the magnetic polarity stratigraphy of Site 605 is based in large part upon interpretation the location of magnetozones and magnetozone 
boundaries is still open to question, and we offer two possible correlations with the magnetic polarity time scale. Biostratigraphic correlation (Moullade et al., this volume) with magnetostratigraphic studies of the same time interval (Italy, other DSDP sites) may support one of the interpretations and hence increase the precision and usefulness of the magnetic polarity stratigraphy of Site 605.

Our findings suggest that the $0.1 \mathrm{Ma}$ duration of the Cretaceous Subchron C30r, as given in the MPTS (Berggren et al., 1985), is too short and should be expanded at least to $0.5 \mathrm{Ma}$. The upper Paleocene data indicate that Subchron C25n lasted 0.3 Ma rather than the 0.6 Ma assigned to it in the MPTS (Berggren et al., 1985).

\section{ACKNOWLEDGMENTS}

We are grateful to the scientists and technicians who took the cumbersome paleomagnetic samples while on the Glomar Challenger during Leg 93.

\section{REFERENCES}

Alvarez, W., Arthur, M. A., Fischer, A. G., Lowrie, W., Napoleone, G., Premoli Silva, I., and Roggenthen, W. M., 1977. Upper Cretaceous-Paleocene magnetic stratigraphy at Gubbio, Italy. V. Type section for the late Cretaceous/Paleocene geomagnetic reversal time scale. Geol. Soc. Am. Bull., 88:383-389.

Berggren, R. F., Kent, D. V., and Flynn, J. J., 1985. Paleogene geochronology and chronostratigraphy. In Snelling, N. J. (Ed.), The Chronology of the Geological Record. Geol. Soc. London Mem., 10:141-195.

Butler, R. F., Lindsay, E. H., Jacobs, L. L., and Johnson, N. M. 1977. Magnetostratigraphy of the Cretaceous-Tertiary boundary in the San Juan Basin, New Mexico. Nature, 284:375.

Channell, J. E. T., and Medizza, F., 1981. Upper Cretaceous and Paleogene magnetic stratigraphy and biostratigraphy from the Venetian (southern) Alps. Earth Planet. Sci. Lett., 55:419-432.

Chave, A. D., 1984. Lower Paleocene-Upper Cretaceous magnetostratigraphy, Sites 525, 527, 528, and 529, Deep Sea Drilling Project Leg 74. In Moore, T. C., Jr., Rabinowitz, P. D., et al., Init. Repts. DSDP, 74: Washington (U.S. Govt. Printing Office), 525-531.

Dankers, P. H. M., 1978. Magnetic properties of dispersed natural iron-oxides of known grain-size [Ph.D. thesis],. State University of Utrecht, The Netherlands.

Hardenbol, J., and Berggren, W. A., 1978. A new Paleogene numerical time scale. Am. Assoc. Pet. Geol., Stud. Geol., 6:213-234.

Hartstra, R. L., 1982. Grain-size dependence of initial susceptibility and saturation magnetization-related parameters of four natural magnetites in the PSD-MD range. Geophys. J. R. Astr. Soc., 71: 477-495.
Hsü, K. J., LaBrecque, J., Percival, S. F., Wright, R. C., Gombos, A. M., Pisciotto, K., Tucker, P., Peterson, N., McKenzie, A. J., Weissert, H., Karpoff, A. M., Carman, M. F., Jr., and Schreiber, E., 1984. Numerical ages of Cenozoic biostratigraphic datum levels: results of South Atlantic Leg 73 drilling. Geol. Soc. Am. Bull., 95: 863-876.

Keating, B. H., and Herrero-Bervera, E., 1984. Magnetostratigraphy of Cretaceous and Early Cenozoic sediments of Deep Sea Drilling Project Site 530, Angola Basin. In Hay, W. W., Sibuet, J. C., et al., Init. Repts. DSDP, 75: Washington (U.S. Govt. Printing Office), 1211-1218.

LaBrecque, J. L., Hsü, K. J., Carman, M. F., Jr., Karpoff, A. M., McKenzie, J. A., Percival, S. F., Jr., Petersen, N. P., Pisciotto, K. A., Schrieber, E., Tauxe. L., Tucker, P., Weissert, H. J., and Wright, R., 1983. DSDP Leg 73: Contribution to Paleogene stratigraphy in nomenclature, chronology and sedimentation rates. Paleoecol., $\mathrm{Pa}$ leogeogr., Paleoclimatol., 42:91-125.

Langereis, C. G., 1979. An attempt to correlate two adjacent Tortonian marine clay sections in western Crete using magnetostratigraphic methods. Utrecht Micropaleontol. Bull., 21:193-214.

Larson, P. A., and Opdyke, N. D., 1979. Paleomagnetic results from Early Tertiary/Late Cretaceous sediments of Site 384. In Tucholke, B. E., Vogt, P. R., et al., Init. Repts. DSDP, 43: Washington (U.S. Govt. Printing Office), 785-788.

Lowrie, W., and Alvarez, W., 1981. One hundred million years of geomagnetic polarity history. Geology, 9:329-397.

Lowrie, W., Alvarez, W., Napoleone, G., Perch-Nielsen, K., Permoli Silva, I., and Tourmakine, M., 1982. Paleocene magnetic stratigraphy in Umbrian pelagic carbonate rocks: Contessa sections, Gubbio. Geol. Soc. Am. Bull., 93:414-432.

Napoleone, G., Premoli Silva, I., Heller, F., Cheli, P., Corezzi, S., and Fischer, A. G., 1983. Eocene magnetic stratigraphy at Gubbio, Italy, and its implications for Paleogene geochronology. Geol. Soc. Am. Bull., 94:181-194.

Ness, G., Levi, S., and Crouch, R., 1980. Marine magnetic anomaly time scales for the Cenozoic and Late Cretaceous: a precise, critique and synthesis. Rev. Geophys. Space Phys. 18(4):753-770.

Smit, J., and Van der Kaars, S., 1984. Terminal Cretaceous extinctions in the Hell Creek area, Montana: compatible with catastrophic extinction. Science, 233:1177-1179.

Tauxe, L., Tucker, P., Petersen, N., and LaBrecque, J., 1983. The magnetostratigraphy of Leg 73. Paleoecol., Paleogeogr., Paleoclimatol., 42:65-90.

Vail, P. R., Mitchum, R. M., 1979. Global cycles of relative changes of sea level from seismic stratigraphy. In Watkins, J. S., Montadert, C., and Dickerson, P. W. (Eds.), Geological and Geophysical Investigations of Continental Margins. Am. Assoc. Pet. Geol. Mem., 29:469-472.

Zijderveld, J. D. A., 1967. A. C. demagnetization of rocks: analysis of results. In Collinson, D. W. Creer, K. M., and Runcorn, S. K. (Eds.), Methods in Paleomagnetism: Amsterdam (Elsevier), pp. 254-286.

Date of Initial Receipt: 16 April 1985

Date of Acceptance: 25 February 1986 